\title{
Targeting FLT3 Mutations in Acute Myeloid Leukemia
}

\author{
Riad El Fakih, Walid Rasheed, Yousef Hawsawi (1), Maamoun Alsermani and Mona Hassanein * \\ King Faisal Specialist Hospital and Research Center Riyadh, Riyadh 11211, Saudi Arabia; \\ relfakih1@kfshrc.edu.sa (R.E.F.); wrasheed@kfshrc.edu.sa (W.R.); yhawsawi@kfshrc.edu.sa (Y.H.); \\ MALSERMANI@kfshrc.edu.sa (M.A.) \\ * Correspondence: mhassanein@kfshrc.edu.sa
}

Received: 30 October 2017; Accepted: 4 January 2018; Published: 8 January 2018

\begin{abstract}
The FMS-like tyrosine kinase 3 (FLT3) pathway has an important role in cellular proliferation, survival, and differentiation. Acute myeloid leukemia (AML) patients with mutated FLT3 have a large disease burden at presentation and a dismal prognosis. A number of FLT3 inhibitors have been developed over the years. The first-generation inhibitors are largely non-specific, while the second-generation inhibitors are more specific and more potent. These inhibitors are used to treat patients with FLT3-mutated AML in virtually all disease settings including induction, consolidation, maintenance, relapse, and after hematopoietic cell transplantation (HCT). In this article, we will review the use of FLT3 inhibitors in AML.
\end{abstract}

Keywords: FMS-like tyrosine kinase 3; acute myeloid leukemia; Midostaurine

\section{Introduction}

The FMS-like tyrosine kinase 3 (FLT3) gene, which is located on chromosome 13q12, encodes the FLT3 tyrosine kinase receptor expressed on the surface of $\mathrm{CD} 34^{+}$hematopoietic stem cells and other immature hematopoietic progenitors. It is a type- 1 transmembrane receptor tyrosine kinase consisting of an extracellular domain, transmembrane domain, and an intracellular tyrosine kinase domain. FLT3 has five Ig domains in its extracellular domain and two kinase domains in its intracellular domain. FLT3 is a class III receptor tyrosine kinase, other members are platelet-derived growth factor receptor (PDGFR), macrophage colony-stimulating factor receptor (FMS), and stem cell factor receptor (c-KIT). Like other class III members, upon activation, the FLT3 tyrosine kinase promotes the activation of downstream pathways involving phosphatidylinositol-3 kinase (PI3K), AKT, mammalian target of rapamycin (mTOR), RAS, and extracellular signal-related kinase (ERK) (Figure 1). Although the activation of the receptor is normally ligand dependent, mutations also constitutivelly activate the receptor and the cells uncontrolled proliferation [1]. Acute myeloid leukemia (AML) is a heterogeneous disease characterized by multiple genetic aberrations [2]. Approximately $20-30 \%$ of AML patients carry an internal tandem duplication (ITD) mutation in the FLT3 gene, which leads to uncontrolled cellular proliferation, survival, and differentiation through constitutive activation of FLT3 [3]. The prognostic impact of the ITD of FLT3 (FLT3-ITD) depends on the allelic ratio. Studies have shown that patients with a low FLT3-ITD allelic ratios $(<0.5)$ have a favorable prognosis in the presence of a nucleophosmin (NPM1) mutation, in comparison to those without FLT3-ITD in the presence of NPM1 mutation. On the other hand, patients with a high FLT3-ITD allelic ratios $(\geq 0.5)$ carry a dismal prognosis in the absence of an NPM1 mutation [4-6], and these are considered as one of the adverse risk groups in the 2017 European LeukemiaNet risk stratification [7].

Mutations in the tyrosine kinase domain (TKD) of FLT3 are less frequent (7\%) and currently have no clinically significant impact [8]. FLT3-mutated AML is frequently found in patients with cytogenetically normal AML [9] and portends a poor prognosis in these patients [10], especially those less than 60 years old [11]. The Southwest Oncology Group (SWOG) trial 9031 enrolled 140 elderly 
AML patients aged over 55 years, demonstrated no significant impact of ITD mutations on the overall survival of patients with mutations (34\%) [12]. Another study enrolled 380 AML patients, $12 \%$ of whom had an FLT3-ITD mutation, and also showed no impact of FLT3-ITD on the outcome of the elderly AML patients [13]. However, two retrospective studies showed poor outcomes for FLT3-mutated elderly patients $[14,15]$. A number of trials already published and multiple other trials are underway to investigate the effects of targeting FLT3 on the outcomes of AML patients.

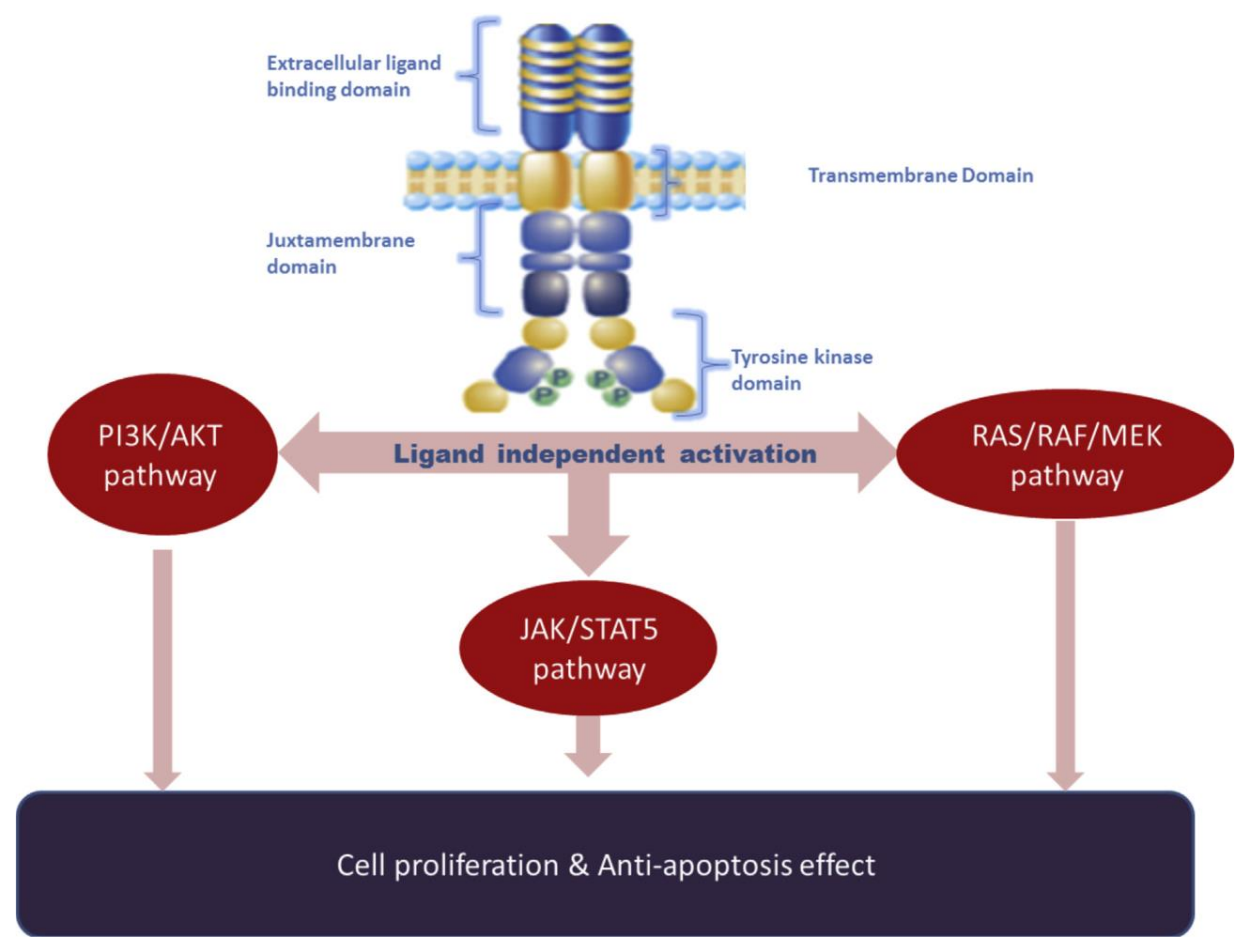

Figure 1. FLT3 activation pathway.

\section{Targeting FLT3 Mutations in AML}

The prognostic impact of FLT3 mutations has made FLT3 an interesting target. In preclinical studies, FLT3 inhibitors were capable of inhibiting FLT3 phosphorylation and inducing apoptosis of the cell as a result $[16,17]$.

In early clinical studies using non-selective FLT3 inhibitors such as sunitinib and lestaurtinib, which usually target more than one member of class III tyrosine kinases, however, high drug concentrations were needed to induce sustained inhibition. Recent development of more specific FLT3 inhibitors led to a more constant effect and better tolerability than those non-selective inhibitors (Table 1) [18]. Despite that, responses to FLT3 inhibitors are usually transient due to the emergence of resistant mutations [19]. The acquisition of point mutations in the ATP binding site of the TKD of FLT3 is the primary cause of resistance to two commonly used FLT3 inhibitors: midostaurin [20] and sorafenib [21]. Other proposed mechanisms of resistance include the stimulation of antiapoptotic proteins such as BCL2, MCL1, and BCL-x [22], and the activation of different pro-survival pathways, including MEK/ERK, PI3K/AKT/mTOR, and STAT5/PIM pathways, in addition to increased expression of FLT3 ligands [23].

\section{Non-Selective FLT3 Inhibitors}

\subsection{Sunitinib (SU11248)}

Sunitinib is a multitargeted tyrosine kinase inhibitor that can inhibit c-KIT, kinase insert domain receptor (KDR), and PDGFR kinases, as well as FLT3. Currently, it is used for treating renal cell 
carcinoma, gastrointestinal stromal tumors, and neuroendocrine tumors [24]. In AML with FLT3-ITD, sunitinib has led to short remissions and significant toxicities as a single agent in a phase I study [25]. In phase I/II trials recruited elderly AML patients with FLT3 mutations, sunitinib in combination with intensive chemotherapy demonstrated a complete remission/complete remission with incomplete hematological recovery (CR/CRi) rate of 59\% with relapse-free survival of 1 year. Dose-limiting toxicity (DLT) included prolonged hematotoxicity and hand-foot syndrome [26].

\subsection{Lestaurtinib (CEP701)}

Lestaurtinib targeting both mutant and wild-type JAK2 is also a potent FLT3 inhibitor. It showed biological and clinical activity when used as a monotherapy in patients with relapsed/refractory AML [27]. In a subsequent phase II trial that included old, unfit, and previously untreated AML patients with either mutated or wild-type FLT3, lestaurtinib treatment as a single agent for 8 weeks led to non-sustained reduction in blasts [28]. In an intention to study salvage chemotherapy followed by lestaurtinib, 29 patients in the lestaurtinib arm achieved CR or partial remission (PR), while no overall survival (OS) rate difference was observed in comparison with that of 23 patients in the control arm. Of note, more patients in the lestaurtinib arm than those in the control arm discontinued the treatment due to adverse events [29]. In the UK MRC AML15 and the NCRI AML17 studies, lestaurtinib failed to demonstrate any significant clinical benefit in terms of remission and survival rates when added sequentially to standard front-line chemotherapy to treat FLT3-mutated AML patients included in those two prospective randomized clinical trials. However, correlative studies indicated improved OS and reduced rates of relapse in patients who achieved sustained FLT3 inhibition of $>85 \%$ [30].

\subsection{Tandutinib}

Tandutinib was able to inhibit proliferation of hematopoietic stem cells in vivo, which have FLT3-ITD mutations as well as mutations in PDGFR or c-KIT [31]. In a clinical phase I study, tandutinib showed some activity for patients with refractory or relapsed AML with FLT3-ITD mutations. However, the DLT was mainly muscle weakness that was reversible, as well as manageable nausea and vomiting [32].

\subsection{Quizartinib (AC220)}

Quizartinib is a second-generation inhibitor against multiple kinases that was developed to treat FLT3-mutated AML; it is also active against AML with PDGFR or c-KIT mutations [33]. The dosing regimen of quizartinib was tested in a phase I study, which included relapsed/refractory AML patients with and without FLT3 mutations. In this study patients received quizartinib in two dose regimen either daily for a 28-day cycle or intermittently (2 weeks on and 2 weeks off); grade 3 QTc prolongation was the DLT [34]. Despite the promising response rates (61\% to $72 \%)$ to quizartinib treatment as a single agent in phase II studies-which included patients with relapsed and refractory AML and even patients who had relapsed after hematopoietic stem cell transplantation (HCT) - relapse within the first 3 months occurred in up to $50 \%$ of the patients $[35,36]$.

\subsection{Sorafenib}

Sorafenib is a multitargeted agent approved for the treatment of hepatocellular carcinoma as it inhibits RAF-1, and renal cell carcinoma as it inhibits vascular endothelial growth factor receptor (VEGFR), as well as PDGFR and c-KIT [37]. Sorafenib is also a potent FLT3 inhibitor that led to a marked reduction in bone marrow and peripheral blood blasts in all patients with FLT3 mutations who were involved in a phase I study using sorafenib as a single agent against refractory or relapsed AML, while there was no DLT after oral administration with 200 to $400 \mathrm{mg}$ twice daily [38]. Due to the safety profile, combined chemotherapy with other drugs including hypomethylating agents has further been conducted. In the relapse and refractory settings, sorafenib combined with idarubicin or high-dose cytarabine was safe, and induced overall CR rates from $75 \%$ to $92 \%$ of patients with mutated FLT3 [39]. 
Another phase II study in the relapse and refractory settings, which use sorafenib in combination with azacitidine, demonstrated an overall response rate of $46 \%$ with minimal toxicity. This allowed patients to have subsequently HCT [40]. Furthermore, a phase II study was carried out for combination therapy using sorafenib with idarubicin or cytarabine during induction and consolidation, followed by treatment with sorafenib as a single agent for up to 1 year as maintenance for patients who completed consolidation. The results showed very high CR rates with complete eradication of FLT3-mutated clones in more than $50 \%$ of the patients. After a median follow-up of 9 months (range, 1-16 months), however, 55\% of patients relapsed [41]. Moreover, the randomized placebo-controlled SAL-SORAML trial that involved 267 younger patients with newly diagnosed AML reported better event-free survival and relapse-free survival but not OS in patients who received sorafenib vs. placebo in the upfront setting [42].

\section{Selective FLT3 Inhibitors}

\subsection{Midostaurin (PKC412)}

Midostaurin is active against both FLT3-ITD and FLT3-TKD mutations. When used as a single agent at a dose of $75 \mathrm{mg}, 3$ times daily, a significant reduction in peripheral blasts was seen in $70 \%$ of 20 patients studied. The treatment was well tolerated by the patients, aside from two fatal pulmonary events with unknown etiology [43]. The addition of midostaurin to induction and consolidation therapy in patients with newly diagnosed AML at a dose of $50 \mathrm{mg}$ twice daily resulted in an $80 \%$ CR rate; the OS rate at 1 and 2 years was similar irrespective of FLT3 mutation status [44]. In a phase II randomized study, 95 patients with AML or high-risk myelodysplastic syndrome (MDS) were treated with oral administration of midostaurin at 50 or $100 \mathrm{mg}$ twice daily. This treatment led to more than $50 \%$ reduction in circulating and bone marrow blasts and the response was more prominent in patients with FLT3 mutations ( $71 \%$ vs. $42 \%$ ) [45]. Subsequently, a phase I trial studied the combination of midostaurin with all-trans retinoic acid and CLAG (cladribine, cytarabine, granulocyte colony-stimulating factor) chemotherapy for the treatment of relapsed/refractory AML and showed an overall response rate (ORR) of 33\% (CR and CRi) [46]. The RATIFY study randomized over 700 young patients (range 18-59 years) with untreated AML and FLT3-ITD (77\%) or FLT3-TKD (23\%) mutation to receive midostaurin or placebo with induction chemotherapy. This multi-institutional, multinational, double-blind, randomized trial reported a significant improvement in OS of $23 \%$ (hazard ratio 0.77 ) in favor of midostaurin even when patients who underwent transplantation (57\%) were censored; the benefit of midostaurin was consistent across FLT3 mutation type (ITD vs. TKD) and allelic mutation fraction (low vs. high). In addition, the event-free survival post transplantation was significantly improved in patients who were treated with midostaurin (hazard ratio 0.84; $p=0.025$ ) $[47,48]$. Midostaurin is the first targeted therapy approved by the Food and Drug Administration for the treatment of FLT3-mutant AML in the US [49].

\subsection{Gilteritinib (ASP2215)}

Gilteritinib is a second-generation selective potent inhibitor of FLT3 and AXL (a member of the TAM receptor tyrosine kinase family). Results of a phase I/II trial of gilteritinib use in FLT3-mutated refractory/relapsed AML showed an ORR of $57 \%$ that reached $63 \%$ with higher drug doses ( $\geq 80 \mathrm{mg}$ ) [50]. Gilteritinib is now being tested in multiple phase III trials in comparison to other salvage regimens in the relapse/refractory setting (NCT02421939, NCT03182244), as maintenance in first CR following induction/consolidation (NCT02927262) or after allogeneic HCT (NCT02997202), and in combination with azacitidine vs. azacitidine alone in patients with FLT3-ITD ineligible for intensive chemotherapy (NCT02752035). 


\section{Future Directions}

The main concern when using FLT3 inhibitors is the development of resistance. Several trials using different agents (e.g., AMG 925, SAR302503, ponatinib, G-749) were conducted to overcome this problem [51-54].

Crenolanib is a pan-selective FLT3 inhibitor believed to bypass resistance caused by the development of TKD mutations in the activation loop, which is the main mechanism of resistance to quizartinib [55]. However, in a phase II study, crenolanib showed better activity in FLT3 inhibitor-naive patients compared with previously treated patients [56], and currently it is being tested in the front-line setting in a phase III trial comparing crenolanib vs. midostaurin after induction and consolidation (NCT03258931). Another phase III trial is comparing chemotherapy combined with crenolanib vs. chemotherapy alone in the relapse/refractory setting in patients with mutated FLT3-ITD AML (NCT02298166).

Targeting other survival pathways together with FLT3 is an interesting approach. Multiple in vitro experiments showed synergism by combining midostaurin with an mTOR or PI3K inhibitor and sunitinib with an mTOR or MAPK-ERK1/2 inhibitor [57-60]. A phase I trial combining the mTOR inhibitor RAD001 with midostaurin is ongoing (NCT00819546).

Patients with FLT3-ITD AML have a high rate of relapse even after allogeneic HCT. FLT3 inhibitors used as post-transplant maintenance to reduce the risk of relapse is being actively investigated. Quizartinib treatment as a maintenance therapy for FLT3-mutated AML patients in CR post transplantation was investigated in a multicenter phase I study. Only one out of 13 patients experienced relapse in that study (despite using doses $<60 \mathrm{mg}$ ) [61]. Another phase I study of sorafenib maintenance post transplantation starting between day 45 and 120 showed that the drug is well tolerated and the OS was impressive at 95\% at one year post HCT [62]. These highly promising results deserve further evaluation in randomized clinical trials.

Table 1. Phases of development and major toxicities of FMS-like tyrosine kinase 3 (FLT3) inhibitors.

\begin{tabular}{|c|c|c|c|c|}
\hline FLT3 Inhibitors & Selectivity & Targets & $\begin{array}{c}\text { Phases of } \\
\text { Development }\end{array}$ & Toxicity \\
\hline $\begin{array}{l}\text { Sunitinib } \\
\text { (SU11248) }\end{array}$ & Non-selective & $\begin{array}{c}\text { c-KIT, KDR PDGFR, and } \\
\text { FLT3 }\end{array}$ & Phase II [26] & $\begin{array}{c}\text { Decreased appetite, } \\
\text { headache, GI symptoms }\end{array}$ \\
\hline $\begin{array}{l}\text { Lestaurtinib } \\
\text { (CEP701) }\end{array}$ & Non-selective & $\begin{array}{l}\text { Mutant and wild-type } \\
\text { JAK2, and FLT3 }\end{array}$ & $\begin{array}{c}\text { Phase II [28] } \\
\text { Phase III }[29,30]\end{array}$ & $\begin{array}{l}\text { Infections, sepsis, } \\
\text { myocardial infarction }\end{array}$ \\
\hline $\begin{array}{l}\text { Tandutinib } \\
\text { (CT53518) }\end{array}$ & Non-selective & PDGFR, c-KIT, and FLT3 & Phase I [32] & Muscle weakness \\
\hline $\begin{array}{l}\text { Quizartinib } \\
\text { (AC220) }\end{array}$ & Non-selective & $\begin{array}{l}\text { Multikinase inhibitor } \\
\text { PDGFR, c-KIT, and FLT3 }\end{array}$ & $\begin{array}{c}\text { Phase I [34] } \\
\text { Phase II }[35,36]\end{array}$ & QTc prolongation \\
\hline Sorafenib & Non-selective & $\begin{array}{c}\text { RAF-1, VEGFR, PDGFR, } \\
\text { c-KIT, and FLT3 }\end{array}$ & $\begin{array}{c}\text { Phase I [38,39] } \\
\text { Phase II [39-41] } \\
\text { Phase III [42] }\end{array}$ & Skin rash, fatigue, diarrhea \\
\hline $\begin{array}{l}\text { Midostaurin } \\
\quad(\mathrm{PKC} 412)\end{array}$ & Selective & FLT3-ITD and FLT3-TKD & $\begin{array}{c}\text { Phase I }[43,44,46] \\
\text { Phase II }[45] \\
\text { Phase III }[47,48]\end{array}$ & $\begin{array}{c}\text { Fever, flu-like symptoms, } \\
\text { mouth sores, unusual } \\
\text { bleeding or bruising }\end{array}$ \\
\hline $\begin{array}{l}\text { Gilteritinib } \\
\text { (ASP2215) }\end{array}$ & Selective & FLT3/AXL & $\begin{array}{c}\text { Phase I/II [50] } \\
\text { Phase III [ongoing] }\end{array}$ & $\begin{array}{l}\text { Diarrhea, fatigue, high liver } \\
\text { function tests (LFT) }\end{array}$ \\
\hline
\end{tabular}

c-KIT, v-kit Hardy-Zuckerman 4 feline sarcoma viral oncogene homolog; KDR, kinase insert domain receptor; PDGFR, platelet-derived growth factor receptor; FLT3, FMS-like tyrosine kinase 3; JAK2, Janus Kinase 2; VEGFR, vascular endothelial growth factor receptor; RAF-1, v-raf-1 murine leukemia viral oncogene homolog 1; AXL, a member of the TAM receptor tyrosine kinase family.

Conflicts of Interest: The authors declare no conflict of interest.

\section{References}

1. Grafone, T.; Palmisano, M.; Nicci, C.; Storti, S. An overview on the role of FLT3-tyrosine kinase receptor in acute myeloid leukemia: Biology and treatment. Oncol. Rev. 2012, 6, e8. [CrossRef] [PubMed] 
2. Kornblau, S.M.; Womble, M.; Qiu, Y.H.; Jackson, C.E.; Chen, W.; Konopleva, M.; Estey, E.H.; Andreeff, M. Simultaneous activation of multiple signal transduction pathways confers poor prognosis in acute myelogenous leukemia. Blood 2006, 108, 2358-2365. [CrossRef] [PubMed]

3. Fröhling, S.; Scholl, C.; Levine, R.L.; Loriaux, M.; Boggon, T.J.; Bernard, O.A.; Berger, R.; Döhner, H.; Döhner, K.; Ebert, B.L.; et al. Identification of driver and passenger mutations of FLT3 by high-throughput DNA sequence analysis and functional assessment of candidate alleles. Cancer Cell 2007, 12, 501-513. [CrossRef] [PubMed]

4. Pratcorona, M.; Brunet, S.; Nomdedéu, J.; Ribera, J.M.; Tormo, M.; Duarte, R.; Escoda, L.; Guàrdia, R.; de Llano, M.P.Q.; Salamero, O.; et al. Favorable outcome of patients with acute myeloid leukemia harboring a low-allelic burden FLT3-ITD mutation and concomitant NPM1 mutation: Relevance to post-remission therapy. Blood 2013, 121, 2734-2738. [CrossRef] [PubMed]

5. Schlenk, R.F.; Kayser, S.; Bullinger, L.; Kobbe, G.; Casper, J.; Ringhoffer, M.; Held, G.; Brossart, P.; Lübbert, M.; Salih, H.R.; et al. Differential impact of allelic ratio and insertion site in FLT3-ITD positive AML with respect to allogeneic transplantation. Blood 2014, 124, 3441-3449. [CrossRef] [PubMed]

6. $\quad$ Linch, D.C.; Hills, R.K.; Burnett, A.K.; Khwaja, A.; Gale, R.E. Impact of FLT3 ${ }^{\text {ITD }}$ mutant allele level on relapse risk in intermediate-risk acute myeloid leukemia. Blood 2014, 124, 273-276. [CrossRef] [PubMed]

7. Döhner, H.; Estey, E.; Grimwade, D.; Amadori, S.; Appelbaum, F.R.; Büchner, T.; Dombret, H.; Ebert, B.L.; Fenaux, P.; Larson, R.A.; et al. Diagnosis and management of AML in adults: 2017 ELN recommendations from an international expert panel. Blood 2017, 129, 424-447. [CrossRef] [PubMed]

8. Abu-Duhier, F.M.; Goodeve, A.C.; Wilson, G.A.; Care, R.S.; Peake, I.R.; Reilly, J.T. Identification of novel FLT-3 Asp835 mutations in adult acute myeloid leukaemia. Br. J. Haematol. 2001, 113, 983-988. [CrossRef] [PubMed]

9. Schnittger, S.; Schoch, C.; Dugas, M.; Kern, W.; Staib, P.; Wuchter, C.; Löffler, H.; Sauerland, C.M.; Serve, H.; Büchner, T.; et al. Analysis of FLT3 length mutations in 1003 patients with acute myeloid leukemia: Correlation to cytogenetics, FAB subtype, and prognosis in the AMLCG study and usefulness as a marker for the detection of minimal residual disease. Blood 2002, 100, 59-66. [CrossRef] [PubMed]

10. Thiede, C.; Steudel, C.; Mohr, B.; Schaich, M.; Schakel, U.; Platzbecker, U.; Wermke, M.; Bornhauser, M.; Ritter, M.; Neubauer, A.; et al. Analysis of FLT3-activating mutations in 979 patients with acute myelogenous leukemia: Association with FAB subtypes and identification of subgroups with poor prognosis. Blood 2002, 99, 4326-4335. [CrossRef] [PubMed]

11. Kiyoi, H.; Naoe, T.; Nakano, Y.; Yokota, S.; Minami, S.; Miyawaki, S.; Asou, N.; Kuriyama, K.; Jinnai, I.; Shimazaki, C. Prognostic implication of FLT3 and N-RAS gene mutations in acute myeloid leukemia. Blood 1999, 93, 3074-3080. [PubMed]

12. Stirewalt, D.L.; Kopecky, K.J.; Meshinchi, S.; Appelbaum, F.R.; Slovak, M.L.; Willman, C.L.; Radich, J.P. FLT3, RAS, and TP53 mutations in elderly patients with acute myeloid leukemia. Blood 2001, 97, 3589-3595. [CrossRef] [PubMed]

13. Daver, N.; Dumlao, T.L.; Ravandi, F.; Pierce, S.; Borthakur, G.; Pemmaraju, N.; Nazha, A.; Faderl, S.; Jabbour, E.; Garcia-Manero, G. Effect of NPM1 and FLT3 mutations on the outcomes of elderly patients with acute myeloid leukemia receiving standard chemotherapy. Clin. Lymphoma Myeloma Leuk. 2013, 13, 435-440. [CrossRef] [PubMed]

14. Nakano, Y.; Kiyoi, H.; Miyawaki, S.; Asou, N.; Ohno, R.; Saito, H.; Naoe, T. Molecular evolution of acute myeloid leukaemia in relapse: Unstable N-ras and FLT3 genes compared with p53 gene. Br. J. Haematol. 1999, 104, 659-664. [CrossRef] [PubMed]

15. Rombouts, W.J.; Blokland, I.; Lowenberg, B.; Ploemacher, R.E. Biological characteristics and prognosis of adult acute myeloid leukemia with internal tandem duplications in the Flt3 gene. Leukemia 2000, 14, 675-683. [CrossRef] [PubMed]

16. Levis, M.; Allebach, J.; Tse, K.-F.; Zheng, R.; Baldwin, B.R.; Smith, B.D.; Jones-Bolin, S.; Ruggeri, B.; Dionne, C.; Small, D. A FLT3-targeted tyrosine kinase inhibitor is cytotoxic to leukemia cells in vitro and in vivo. Blood 2002, 99, 3885-3891. [CrossRef] [PubMed]

17. O'Farrell, A.-M.; Abrams, T.J.; Yuen, H.A.; Ngai, T.J.; Louie, S.G.; Yee, K.W.H.; Wong, L.M.; Hong, W.; Lee, L.B.; Town, A. SU11248 is a novel FLT3 tyrosine kinase inhibitor with potent activity in vitro and in vivo. Blood 2003, 101, 3597-3605. [CrossRef] [PubMed] 
18. Wander, S.A.; Levis, M.J.; Fathi, A.T. The evolving role of FLT3 inhibitors in acute myeloid leukemia: Quizartinib and beyond. Ther. Adv. Hematol. 2014, 5, 65-77. [CrossRef] [PubMed]

19. Weisberg, E.; Sattler, M.; Ray, A.; Griffin, J.D. Drug resistance in mutant FLT3-positive AML. Oncogene 2010, 29, 5120-5134. [CrossRef] [PubMed]

20. Cools, J.; Mentens, N.; Furet, P.; Fabbro, D.; Clark, J.J.; Griffin, J.D.; Marynen, P.; Gilliland, D.G. Prediction of resistance to small molecule FLT3 inhibitors: Implications for molecularly targeted therapy of acute leukemia. Cancer Res. 2004, 64, 6385-6389. [CrossRef] [PubMed]

21. Zhang, W.; Gao, C.; Konopleva, M.; Chen, Y.; Jacamo, R.O.; Borthakur, G.; Cortes, J.E.; Ravandi, F.; Ramachandran, A.; Andreeff, M. Reversal of acquired drug resistance in FLT3-mutated acute myeloid leukemia cells via distinct drug combination strategies. Clin. Cancer Res. 2014, 20, 2363-2374. [CrossRef] [PubMed]

22. Zeng, Z.; Shi, Y.X.; Samudio, I.J.; Wang, R.Y.; Ling, X.; Frolova, O.; Levis, M.; Rubin, J.B.; Negrin, R.R.; Estey, E.H.; et al. Targeting the leukemia microenvironment by CXCR4 inhibition overcomes resistance to kinase inhibitors and chemotherapy in AML. Blood 2009, 113, 6215-6224. [CrossRef] [PubMed]

23. Chu, S.H.; Small, D. Mechanisms of resistance to FLT3 inhibitors. Drug Resist. Updat. 2009, 12, 8-16. [CrossRef] [PubMed]

24. Demetri, G.D.; van Oosterom, A.T.; Garrett, C.R.; Blackstein, M.E.; Shah, M.H.; Verweij, J.; McArthur, G.; Judson, I.R.; Heinrich, M.C.; Morgan, J.A.; et al. Efficacy and safety of sunitinib in patients with advanced gastrointestinal stromal tumour after failure of imatinib: A randomised controlled trial. Lancet 2006, 368, 1329-1338. [CrossRef]

25. Fiedler, W.; Serve, H.; Dohner, H.; Schwittay, M.; Ottmann, O.G.; O’Farrell, A.M.; Bello, C.L.; Allred, R.; Manning, W.C.; Cherrington, J.M.; et al. A phase 1 study of SU11248 in the treatment of patients with refractory or resistant acute myeloid leukemia (AML) or not amenable to conventional therapy for the disease. Blood 2005, 105, 986-993. [CrossRef] [PubMed]

26. Fiedler, W.; Kayser, S.; Kebenko, M.; Janning, M.; Krauter, J.; Schittenhelm, M.; Götze, K.; Weber, D.; Göhring, G.; Teleanu, V.; et al. A phase I/II study of sunitinib and intensive chemotherapy in patients over 60 years of age with acute myeloid leukaemia and activating FLT3 mutations. Br. J. Haematol. 2015, 169, 694-700. [CrossRef] [PubMed]

27. Smith, B.D.; Levis, M.; Beran, M.; Giles, F.; Kantarjian, H.; Berg, K.; Murphy, K.M.; Dauses, T.; Allebach, J.; Small, D. Single-agent CEP-701, a novel FLT3 inhibitor, shows biologic and clinical activity in patients with relapsed or refractory acute myeloid leukemia. Blood 2004, 103, 3669-3676. [CrossRef] [PubMed]

28. Knapper, S.; Burnett, A.K.; Littlewood, T.; Kell, W.J.; Agrawal, S.; Chopra, R.; Clark, R.; Levis, M.J.; Small, D. A phase 2 trial of the FLT3 inhibitor lestaurtinib (CEP701) as first-line treatment for older patients with acute myeloid leukemia not considered fit for intensive chemotherapy. Blood 2006, 108, 3262-3270. [CrossRef] [PubMed]

29. Levis, M.; Ravandi, F.; Wang, E.S.; Baer, M.R.; Perl, A.; Coutre, S.; Erba, H.; Stuart, R.K.; Baccarani, M.; Cripe, L.D.; et al. Results from a randomized trial of salvage chemotherapy followed by lestaurtinib for FLT3 mutant AML patients in first relapse. Blood 2009, 114, 788. [CrossRef] [PubMed]

30. Knapper, S.; Russell, N.; Gilkes, A.; Hills, R.K.; Gale, R.E.; Cavenagh, J.D.; Jones, G.; Kjeldsen, L.; Grunwald, M.R.; Thomas, I. A randomised assessment of adding the kinase inhibitor lestaurtinib to 1st-line chemotherapy for FLT3-mutated AML. Blood 2016. [CrossRef]

31. Kelly, L.M.; Yu, J.C.; Boulton, C.L.; Apatira, M.; Li, J.; Sullivan, C.M.; Williams, I.; Amaral, S.M.; Curley, D.P.; Duclos, N.; et al. CT53518, a novel selective FLT3 antagonist for the treatment of acute myelogenous leukemia (AML). Cancer Cell 2002, 1, 421-432. [CrossRef]

32. DeAngelo, D.J.; Stone, R.M.; Heaney, M.L.; Nimer, S.D.; Paquette, R.L.; Klisovic, R.B.; Caligiuri, M.A.; Cooper, M.R.; Lecerf, J.M.; Karol, M.D.; et al. Phase 1 clinical results with tandutinib (MLN518), a novel FLT3 antagonist, in patients with acute myelogenous leukemia or high-risk myelodysplastic syndrome: Safety, pharmacokinetics, and pharmacodynamics. Blood 2006, 108, 3674-3681. [CrossRef] [PubMed]

33. Zarrinkar, P.P.; Gunawardane, R.N.; Cramer, M.D.; Gardner, M.F.; Brigham, D.; Belli, B.; Karaman, M.W.; Pratz, K.W.; Pallares, G.; Chao, Q.; et al. AC220 is a uniquely potent and selective inhibitor of FLT3 for the treatment of acute myeloid leukemia (AML). Blood 2009, 114, 2984-2992. [CrossRef] [PubMed]

34. Cortes, J.E.; Kantarjian, H.; Foran, J.M.; Ghirdaladze, D.; Zodelava, M.; Borthakur, G.; Gammon, G.; Trone, D.; Armstrong, R.C.; James, J.; et al. Phase I study of quizartinib administered daily to patients with relapsed or refractory acute myeloid leukemia irrespective of FMS-like tyrosine kinase 3-internal tandem duplication status. J. Clin. Oncol. 2013, 31, 3681-3687. [CrossRef] [PubMed] 
35. Levis, M.J.; Perl, A.E.; Dombret, H.; Döhner, H.; Steffen, B.; Rousselot, P.; Martinelli, G.; Estey, E.H.; Burnett, A.K.; Gammon, G.; et al. Final Results of a Phase 2 Open-Label, Monotherapy Efficacy and Safety Study of Quizartinib (AC220) in Patients with FLT3-ITD Positive or Negative Relapsed/Refractory Acute Myeloid Leukemia After Second-Line Chemotherapy or Hematopoietic Stem Cell Transplantation. Blood 2012, 120, 673 .

36. Cortes, J.E.; Perl, A.E.; Dombret, H.; Kayser, S.; Steffen, B.; Rousselot, P.; Martinelli, G.; Estey, E.H.; Burnett, A.K.; Gammon, G.; et al. Final Results of a Phase 2 Open-Label, Monotherapy Efficacy and Safety Study of Quizartinib (AC220) in Patients $\geq 60$ Years of Age with FLT3 ITD Positive or Negative Relapsed/Refractory Acute Myeloid Leukemia. Blood 2012, 120, 48.

37. Wilhelm, S.M.; Carter, C.; Tang, L.; Wilkie, D.; McNabola, A.; Rong, H.; Chen, C.; Zhang, X.; Vincent, P.; McHugh, M.; et al. BAY 43-9006 exhibits broad spectrum oral antitumor activity and targets the RAF/MEK/ERK pathway and receptor tyrosine kinases involved in tumor progression and angiogenesis. Cancer Res. 2004, 64, 7099-7109. [CrossRef] [PubMed]

38. Zhang, W.; Konopleva, M.; Shi, Y.X.; McQueen, T.; Harris, D.; Ling, X.; Estrov, Z.; Quintas-Cardama, A.; Small, D.; Cortes, J.; et al. Mutant FLT3: A direct target of sorafenib in acute myelogenous leukemia. J. Natl. Cancer Inst. 2008, 100, 184-198. [CrossRef] [PubMed]

39. Ravandi, F.; Cortes, J.E.; Jones, D.; Faderl, S.; Garcia-Manero, G.; Konopleva, M.Y.; O’Brien, S.; Estrov, Z.; Borthakur, G.; Thomas, D. Phase I/II study of combination therapy with sorafenib, idarubicin, and cytarabine in younger patients with acute myeloid leukemia. J. Clin. Oncol. 2010, 28, 1856-1862. [CrossRef] [PubMed]

40. Rollig, C.; Serve, H.; Huttmann, A.; Noppeney, R.; Muller-Tidow, C.; Krug, U.; Baldus, C.D.; Brandts, C.H.; Kunzmann, V.; Einsele, H.; et al. Addition of sorafenib versus placebo to standard therapy in patients aged 60 years or younger with newly diagnosed acute myeloid leukaemia (SORAML): A multicentre, phase 2, randomised controlled trial. Lancet Oncol. 2015, 16, 1691-1699. [CrossRef]

41. Al-Kali, A.; Cortes, J.; Faderl, S.; Jones, D.; Abril, C.; Pierce, S.; Brandt, M.; Kantarjian, H.; Ravandi, F. Patterns of molecular response to and relapse after combination of sorafenib, idarubicin, and cytarabine in patients with FLT3 mutant acute myeloid leukemia. Clin. Lymphoma Myeloma Leuk. 2011, 11, 361-366. [CrossRef] [PubMed]

42. Röllig, C.; Müller-Tidow, C.; Hüttmann, A.; Noppeney, R.; Kunzmann, V.; Baldus, C.D.; Brandts, C.H.; Krämer, A.; Schäfer-Eckart, K.; Neubauer, A.; et al. Sorafenib versus placebo in addition to standard therapy in younger patients with newly diagnosed acute myeloid leukemia: Results from 267 patients treated in the randomized placebo-controlled SAL-Soraml trial. Blood 2014, 124, 6.

43. Stone, R.M.; DeAngelo, D.J.; Klimek, V.; Galinsky, I.; Estey, E.; Nimer, S.D.; Grandin, W.; Lebwohl, D.; Wang, Y.; Cohen, P.; et al. Patients with acute myeloid leukemia and an activating mutation in FLT3 respond to a small-molecule FLT3 tyrosine kinase inhibitor, PKC412. Blood 2005, 105, 54-60. [CrossRef] [PubMed]

44. Stone, R.M.; Fischer, T.; Paquette, R.; Schiller, G.; Schiffer, C.A.; Ehninger, G.; Cortes, J.; Kantarjian, H.M.; DeAngelo, D.J.; Huntsman-Labed, A. Phase IB study of the FLT3 kinase inhibitor midostaurin with chemotherapy in younger newly diagnosed adult patients with acute myeloid leukemia. Leukemia 2012, 26, 2061-2068. [CrossRef] [PubMed]

45. Fischer, T.; Stone, R.M.; Deangelo, D.J.; Galinsky, I.; Estey, E.; Lanza, C.; Fox, E.; Ehninger, G.; Feldman, E.J.; Schiller, G.J.; et al. Phase IIB trial of oral Midostaurin (PKC412), the FMS-like tyrosine kinase 3 receptor (FLT3) and multi-targeted kinase inhibitor, in patients with acute myeloid leukemia and high-risk myelodysplastic syndrome with either wild-type or mutated FLT3. J. Clin. Oncol. 2010, 28, 4339-4345. [CrossRef] [PubMed]

46. Ramsingh, G.; Westervelt, P.; McBride, A.; Stockerl-Goldstein, K.; Vij, R.; Fiala, M.; Uy, G.; Cashen, A.; Dipersio, J.F.; Abboud, C.N. Phase I study of cladribine, cytarabine, granulocyte colony stimulating factor (CLAG regimen) and midostaurin and all-trans retinoic acid in relapsed/refractory AML. Int. J. Hematol. 2014, 99, 272-278. [CrossRef] [PubMed]

47. Stone, R.M.; Mandrekar, S.; Sanford, B.L.; Geyer, S.; Bloomfield, C.D.; Dohner, K.; Thiede, C.; Marcucci, G.; Lo-Coco, F.; Klisovic, R.B.; et al. The Multi-Kinase Inhibitor Midostaurin (M) Prolongs Survival Compared with Placebo (P) in Combination with Daunorubicin (D)/Cytarabine (C) Induction (ind), High-Dose C Consolidation (consol), and As Maintenance (maint) Therapy in Newly Diagnosed Acute Myeloid Leukemia (AML) Patients (pts) Age 18-60 with FLT3 Mutations (muts): An International Prospective Randomized (rand) P-Controlled Double-Blind Trial. Blood 2015, 126, 6. 
48. Stone, R.M.; Mandrekar, S.J.; Sanford, B.L.; Laumann, K.; Geyer, S.; Bloomfield, C.D.; Thiede, C.; Prior, T.W.; Döhner, K.; Marcucci, G. Midostaurin plus chemotherapy for acute myeloid leukemia with a FLT3 mutation. N. Engl. J. Med. 2017, 377, 454-464. [CrossRef] [PubMed]

49. Levis, M. Midostaurin approved for FLT3-mutated AML. Blood 2017. [CrossRef] [PubMed]

50. Levis, M.J.; Perl, A.E.; Altman, J.K.; Cortes, J.E.; Ritchie, E.K.; Larson, R.A.; Smith, C.C.; Wang, E.S.; Strickland, S.A.; Baer, M.R. Results of a first-in-human, phase I/II trial of ASP2215, a selective, potent inhibitor of FLT3/Axl in patients with relapsed or refractory (R/R) acute myeloid leukemia (AML). J. Clin. Oncol. 2015, 7003. [CrossRef]

51. Li, C.; Liu, L.; Liang, L.; Xia, Z.; Li, Z.; Wang, X.; McGee, L.R.; Newhall, K.; Sinclair, A.; Kamb, A. AMG 925 is a dual FLT3/CDK4 inhibitor with the potential to overcome FLT3 inhibitor resistance in acute myeloid leukemia. Mol. Cancer Ther. 2015, 14, 375-383. [CrossRef] [PubMed]

52. Kesarwani, M.; Huber, E.; Azam, M. Overcoming AC220 resistance of FLT3-ITD by SAR302503. Blood Cancer J. 2013, 3, e138. [CrossRef] [PubMed]

53. Zirm, E.; Spies-Weisshart, B.; Heidel, F.; Schnetzke, U.; Böhmer, F.D.; Hochhaus, A.; Fischer, T.; Scholl, S. Ponatinib may overcome resistance of FLT3-ITD harbouring additional point mutations, notably the previously refractory F691I mutation. Br. J. Haematol. 2012, 157, 483-492. [CrossRef] [PubMed]

54. Lee, H.K.; Kim, H.W.; Lee, I.Y.; Lee, J.; Lee, J.; Jung, D.S.; Lee, S.Y.; Park, S.H.; Hwang, H.; Choi, J.-S. G-749, a novel FLT3 kinase inhibitor, can overcome drug resistance for the treatment of acute myeloid leukemia. Blood 2014, 123, 2209-2219. [CrossRef] [PubMed]

55. Smith, C.C.; Lasater, E.A.; Lin, K.C.; Wang, Q.; McCreery, M.Q.; Stewart, W.K.; Damon, L.E.; Perl, A.E.; Jeschke, G.R.; Sugita, M. Crenolanib is a selective type I pan-FLT3 inhibitor. Proc. Natl. Acad. Sci. USA 2014, 111, 5319-5324. [CrossRef] [PubMed]

56. Randhawa, J.K.; Kantarjian, H.M.; Borthakur, G.; Thompson, P.A.; Konopleva, M.; Daver, N.; Pemmaraju, N.; Jabbour, E.; Kadia, T.M.; Estrov, Z. Results of a phase II study of crenolanib in relapsed/refractory acute myeloid leukemia patients (pts) with activating FLT3 mutations. Blood 2014, 124, 389.

57. Mohi, M.G.; Boulton, C.; Gu, T.-L.; Sternberg, D.W.; Neuberg, D.; Griffin, J.D.; Gilliland, D.G.; Neel, B.G. Combination of rapamycin and protein tyrosine kinase (PTK) inhibitors for the treatment of leukemias caused by oncogenic PTKs. Proc. Natl. Acad. Sci. USA 2004, 101, 3130-3135. [CrossRef] [PubMed]

58. Weisberg, E.; Banerji, L.; Wright, R.D.; Barrett, R.; Ray, A.; Moreno, D.; Catley, L.; Jiang, J.; Hall-Meyers, E.; Sauveur-Michel, M. Potentiation of antileukemic therapies by the dual PI3K/PDK-1 inhibitor, BAG956: Effects on BCR-ABL- and mutant FLT3-expressing cells. Blood 2008, 111, 3723-3734. [CrossRef] [PubMed]

59. Ikezoe, T.; Nishioka, C.; Tasaka, T.; Yang, Y.; Komatsu, N.; Togitani, K.; Koeffler, H.P.; Taguchi, H. The antitumor effects of sunitinib (formerly SU11248) against a variety of human hematologic malignancies: Enhancement of growth inhibition via inhibition of mammalian target of rapamycin signaling. Mol. Cancer Ther. 2006, 5, 2522-2530. [CrossRef] [PubMed]

60. Nishioka, C.; Ikezoe, T.; Yang, J.; Takeshita, A.; Taniguchi, A.; Komatsu, N.; Togitani, K.; Koeffler, H.P.; Yokoyama, A. Blockade of MEK/ERK signaling enhances sunitinib-induced growth inhibition and apoptosis of leukemia cells possessing activating mutations of the FLT3 gene. Leuk. Res. 2008, 32, 865-872. [CrossRef] [PubMed]

61. Sandmaier, B.M.; Khaled, S.K.; Oran, B.; Gammon, G.; Trone, D.; Frankfurt, O. Results of a Phase 1 Study of Quizartinib (AC220) As Maintenance Therapy in Subjects with Acute Myeloid Leukemia in Remission Following Allogeneic Hematopoietic Cell Transplantation. Blood 2014, 124, 428.

62. Chen, Y.-B.; Shuli, L.; Andrew, L.A.; Connolly, C.; Del Rio, C.; Valles, B.; Curtis, M.; Ballen, K.K.; Cutler, C.S.; Dey, B.R.; et al. Phase I Trial of Maintenance Sorafenib after Allogeneic Hematopoietic Stem Cell Transplantation for Patients with FLT3-ITD AML. Blood 2014, 124, 671.

(C) 2018 by the authors. Licensee MDPI, Basel, Switzerland. This article is an open access article distributed under the terms and conditions of the Creative Commons Attribution (CC BY) license (http://creativecommons.org/licenses/by/4.0/). 